\title{
Research on female Character shaping in Hayao Miyazaki's animation film
}

\author{
XiangFei Ma \\ School of art,Zhengzhou University of Industry Technology,Zhengzhou451100,China. \\ 18633853@qq.com
}

Keywords: Female characters; Character shaping; Animation film; Hayao Miyazaki

\begin{abstract}
The animated movie role shaping is an important part of the animation film creation, through the study of the characteristics of the animation Character shaping can summed up a animation director's style, as a world famous animation master Hayao Miyazaki, his animated film has its unique role shaping characteristics. This paper based on Hayao Miyazaki's animation film female characters shape as the research object and take Hayao Miyazaki's animation film as the research material to studies the characteristics of the female characters in Hayao Miyazaki's animation film, through the analysis who can summarizes the characteristics of the female characters shaping and provide theoretical basis for the animated character by the research.
\end{abstract}

\section{Introduction}

As the most popular humanism masters of animation in japan, Hayao Miyazaki's animation works are deeply rooted in the hearts of the people from the first animated film Nausicaa of the Valley of The Winds to Spirited Away which is the most popular in the world, Hayao Miyazaki shows a magical world and stories for the audience constantly. These animated feature make the various character girl as leading role and through these psychological change of young girl from the ordinary to the great, from weak to strong, show the power of the women's unique to the audience. Hayao Miyazaki's animated film subverts the traditional gender view, shaping a batch of independent strong woman image and emphasis on women's liberation of personality[1].

This paper based on the female characters of hayao miyazaki animation model as the research target and take the hayao miyazaki's most representative animation production as the research material to analysis the female Character shaping.

\section{The female Character shaping - Women's ideological emancipation}

Japan is a strong feudal ideology country which women's social position is very low and roles of traditional thought that women are inferior to men still exists. In modern Japan women are not allowed to take part in the work but stay as a housewife[2]. In Hayao Miyazaki's animated film, women are no longer protected by male as vulnerable groups, as contrast they always have their own specific ideas and goals, resolute character and independent ability to act, we will analysis from the following three aspects:

Female character's flying ability. In animation, the female characters have remarkable ability reflected in their ability to control the flight or have the ability to fly, Hayao Miyazaki once said: I think expressed by the flight is a break out of the liberation of gravity and the flying is a form of liberation. In his animated films, he gives these female characters ability of flight which reflects the women's liberation in both ideologically and psychologically. Such as Nausica in the film Nausicaa of the Valley of the Winds can free flight by drive the wind flying wings; Sheeta who is the he leading role in the film Castle in the Sky can flying by use pilot rock; Kiki who come from the movie Kiki's Delivery Service can fly on a broom. Either flight by other force or has the ability of flight theirself, these female characters can have more ability than men,and even more outstanding than men in some ways

The labor and the ability to control their own destiny. In traditional ideas the men have labor 
ability and they possession of social resources,so they can control their own destiny,at the same time the women dominated by men and social status is lower because their disadvantages in labor ,But in Hayao Miyazaki's animated film has another kind of situation which the women have unique leadership,and reflects more strong courage than the male character when face to great difficulty.In the movie Princess Mononoke, dada city which imperator was women occupied by the women who controls the economic through their own labor, create their own weapons and used these weapons to fight with the enemy,they can free to joke about men,this scene is impossible to see in the reality Japan.

The character is a performer of animation, animation story play around animated characters and animation character's character changes affect the development of animation plot.It's a feature that the opposition between female character conversion in Hayao miyazaki 's animation creation, the female character development the story theme from cowardice to brave, from weak to have the courage, characters changes their personality through all kinds of hardships. In Spirited Away, for example, Chihiro who laziness and cowardice at beginning and become a brave, kind, know care about people's girl after experience all kinds of difficulties; Sita as the leader in Castle in the Sky who is the girl that can only endure hardship to a women have the courage to challenge difficulties; Sophie in Howl's Moving Castle, although became a old lady by the magic curse, but she freed themselves from the low mood and defeat the witch, lifted the curse finally through efforts herself.

Hayao Miyazaki give these simple kind woman with extraordinary ability through female characters thought liberation to show audience women unique charm, female character also has a strong will and fighting spirit and they can final victory through their own efforts to overcome difficulties[3].

\section{The female Character shaping - the national character}

National character which is the common features of a nation is refers to the state of mind performance on national culture characteristic in the process of groups setting up and development .although Japan's national character is complex but brave is an important aspect of Japanese national character, Hayao Miyazaki's animation film on female characters shaping is clear in the embodiment the national character.

The female character's Strength of outlook on life.The girls age in Hayao Miyazaki's animation film is about 10 years old and the smallest only four years old, their living environment have a common problem,their parents can not accompany with them will, they are under more pressure than other children ,they will be more mature under such family background,this situation makes them brave, independent after suffering ,this accord with the national character of the Japanese nation.May in My Neighbor Totoro is a very brave girl,she carrying corn wants to go to a hospital for his mother to eat and hope mother's illness better soon when the little girl learned her mother was sick, this pure kind,and brave move make the person can't help forgive the impulse of the children[4].

Nausica in film Nausicaa of the Valley of the Winds whose father was killed by the bad guys and mother died to take her father's duty to protect the safety of the valley of the wind,she is strength thin,and lack of experience and faced the threat of enemies killed father and rotting sea, but she still unremitting took everything, solve all kinds of hardships, finally defend the peace of the valley of the wind, and punish the bad man killed his father,this reflects the brave temperament that she has the unique charm beyond men.

The double character of siren and warriors. the female characters in Hayao Miyazaki's animation has magical powers, For example, Kiki in film Kiki's Delivery Service is a siren and can fly on a broom; Sita is the heir to the city of the sky; Princess mononoke is the daughter of Wolf; Ponyo is the the daughter of Neptune. All the female characters are has a unique bride temperament, their status will cause the audience's interest, not just siren, they also have strong personality of soldiers, the Princess mononoke who adopted by Wolf god abandoned by their parents as a child, she is wearing a beast, often with a sharp knife in his hand and struggle the people who destroy the forest , every time she rode on the Wolf rushed in front, in order to defeat the dada city shg attack again and 
again, it is a brave warrior's character[5].

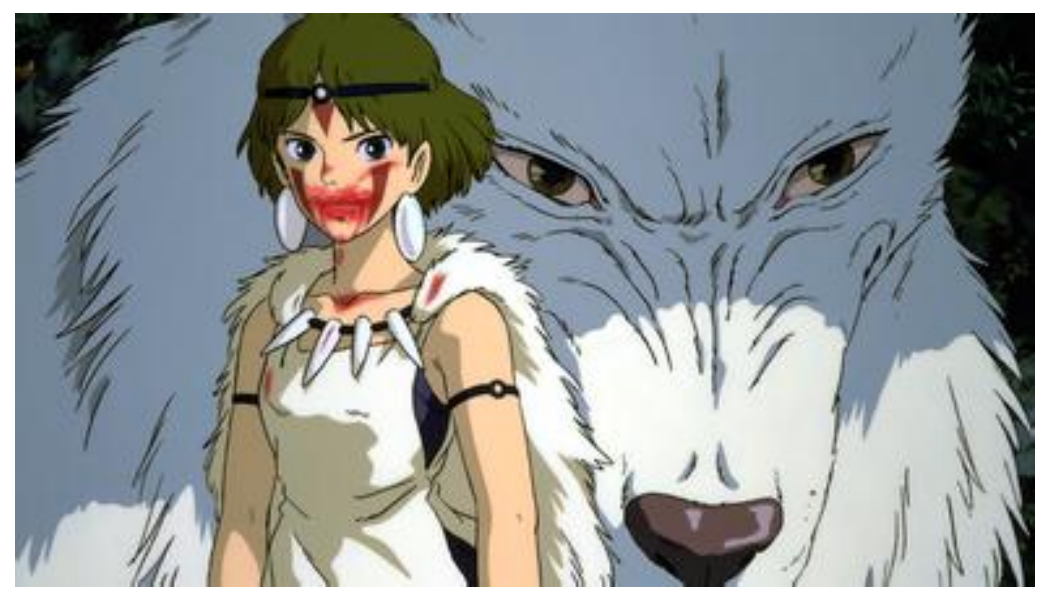

Fig. 1 Princess mononoke

With adventure spirit. Hayao miyazaki's film have several elements: fly girl with super ability, magic, and adventure. Kiki in film Kiki's Delivery Service left home at the age of 13 to find a city can live independently to complete the siren of practice ,but she got to the seaside city is not as she thought enthusiasm, Kiki has met a series of setbacks. Nausicaa in the valley of the wind found human ugliness on her own strength and eventually to realize the human salvation through the power of herself ;although the Chihiro are just an ordinary girl but she has the courage and the spirit of adventure, she decided to go to the home of witch is a huge risk,but she get on a train with courage and start the journey of advanture,finally she save the other people.

\section{Summary}

Through the analysis we can find that the female Character shaping in Hayao Miyazaki's animation film is to abandon the traditional role of male dominance,the female who have an open mind and a strong national character is so vivid and impressive and they has amazing powers[6]. They realize the self growth and implement to others, even for the salvation of the world by overcome the difficulties. Hayao Miyazaki put his beautiful yearning and pursuit rely on these simple kind and brave girl, these characters show Hayao Miyazaki's humanism thought and has a positive meaning for us to character shaping in the animation creation。

\section{References}

[1]Lin Gao .The feature of animation audio-visual language in Animation Film from Up.Movie literature.2010,No. 16,p. 30-31.

[2] Jun Fan.Analysis on the storyboard of animation.Home of drama.2014,No. 8, p. 218-219.

[3] Jian Wu .Discussion in action design of animation role performance. Art Criticism,.2013,No.3,p. 13-116.

[4] Peng Chen .Effects of characteristic motions in animation film.Movie iterature.2015,No.3,p. 83-85.

[5] JianWu.Discussion in action design of animation role performance. Art Criticism,.2013,No.3,p. 13-116.

[6] QingLu.The "experience" performance of the cartoon character.Art Review.2015,No.10,p. 127-129. 